\title{
Effects of Working Memory Treatment using Verb- Carrier Phrases on Language Processing in Persons with Mild Cognitive Impairment
}

\author{
Su Jin Choi ${ }^{\mathrm{a}}$, Jee Eun Sung, Jee Hyang Jeong ${ }^{\mathrm{b}}$, Geon Ha Kim ${ }^{\mathrm{b}, \mathrm{c}}$ \\ ${ }^{a}$ Department of Communication Disorder, Ewha Womans University, Seoul, Korea \\ ${ }^{b}$ Department of Neurology, Ewha Womans University Mokdong Hospital, Ewha Womans University School of Medicine, Seoul, Korea \\ ${ }^{c}$ Ewha Brain Institute, Ewha Womans University, Seoul, Korea
}

\section{Correspondence: Jee Eun Sung, PhD} Department of Communication Disorders, Ewha Womans University, 52 Ewhayeodae-gil, Seodamun-gu, Seoul 03760, Korea

Tel: $+82-2-3277-2208$

Fax: +82-2-3277-2122

E-mail: jeesung@ewha.ac.kr

Received: April 5, 2016

Revised: May 16, 2016

Accepted: May 20, 2016

This work was supported by the National Research Foundation of Korea Grant funded by the Korean Government (NRF-2014S1A5A8018080).

\begin{abstract}
Objectives: The purpose of the study was to investigate the effects of working memory (WM) treatment using verb-carrier phrases on language processing for individuals with mild cognitive impairment $(\mathrm{MCl})$. Methods: A total of eight individuals with $\mathrm{MCl}$ participated in this study. The WM treatment consisted of 12 sessions, twice a week for an hour per day. WM treatment protocol employed verb-carrier phrases to enhance WM span by manipulating semantic span and syntactic complexity at the sentence-level. The treatment protocol consisted of 10 steps: step 1, forward word span repetition; step 2, target sentence repetition; step 3, phrase repetition after chunking sentences; step 4, answering whquestions; step 5, word recognition; step 6, verb-noun matching; step 7, sentence construction using verb-carrier phrases; step 8, recalling word span-forward; step 9, recalling word span-backward; and step 10, target sentence construction. Results: Pre-post comparisons using Wilcoxon signed-ranks tests revealed that there were significant increases in performance on target sentence repetition and word span with treated words. The treatment effects were generalized on the word span forward and visuospatial span backward tasks using untreated items. Treatment effects were additionally generalized onto sentence comprehension and generative naming abilities. Conclusion: The current study suggests that WM treatment using verb-carrier phrases is effective in enhancing the sentence repetition ability, sentence comprehension, WM span and generative naming abilities in people with $\mathrm{MCl}$.
\end{abstract}

Keywords: Mild cognitive impairment, Working memory treatment, Verb carrier phrase
2012년 통계청 조사 결과에 따르면 현재 우리나라의 65세 이상 노년층의 인구는 2000년 약 334만 명에서 2010년 528만 명으로, 점 차 증가하는 추세를 보이고 있으며, 고령인구의 비율이 2-3배 증가 할 것이라고 예측하고 있다. 고령인구의 증가는 노년층에서 두드러 지게 나타나는 치매(dementia)나 경도인지장애(mild cognitive impairment)군과 같은 인지 장애의 비율 증가에 영향을 미치게 된다.

경도인지장애란, 동일 연령에 비해 인지 기능이 저하된 상태로, 일상생활이나 사회생활을 하는 데 있어서는 큰 어려움이 없으나, 기억력의 저하가 동일 연령대에 비하여 상대적으로 과도한 경우를 지칭하는 용어이다(Kim, 2003). 노화가 진행될수록 인지 및 언어
기능의 저하를 보이게 되는데, 이러한 기능의 저하가 대인관계나 일상생활에 현저하게 영향을 미치는 경우에 임상적 의미의 치매라 고 하고, 인지 기능의 저하는 있으나 치매보다는 심하지 않은 경우 를 경도인지장애라고 한다. 알츠하이머성 치매(dementia of Alzheimer's type)의 경우에도 경미한 인지 기능 장애에서 시작해 점차 심 각하게 진행되는 과정을 나타내는데, 경도인지장애군의 일부가 알 츠하이머성 치매로 진행되기도 한다(Kim, 2003).

경도인지장애군은 인지 기능 중 특히 기억력과 일상생활의 기능 적 수행력 저하와 더불어 작업기억(working memory) 결함을 특징 적으로 나타낸다(Petersen et al., 1999). 작업기억이란, 입력된 정보 
를 일시적으로 저장하고, 처리(processing) 및 조작(computation or manipulation)하는 인지적 기제(cognitive mechanism)로서 복잡한 인지적 처리과정에 관여하는 능력이다(Baddeley \& Hitch, 1974). 이러한 작업기억의 감소는 언어처리과정에 부정적인 영향을 미치 는데, 최근 들어 다양한 연구 결과에서 작업기억이 저하될수록 언 어적 과제에서 어려움을 보인다고 하였다(Kemper, Rash, Kynette, \& Norma, 1990; Wright, Capilouto, Srinivasan, \& Fergadiotis, 2011). 작업기억이 감소되면 이를 보상하기 위해 인지적 역량을 재분배하 고 다른 수단을 이용해야 하는데, 다른 수단을 이용할 경우에는 기 존의 역량을 모두 발휘할 수 없게 된다. 그러므로 기존에 비해 입력 된 정보를 처리하는 능력이 감소되고, 언어 및 의사소통의 문제가 발생하게 된다(DeDe, Caplan, Kemtes, \& Waters, 2004). 또한 작업 기억은 어휘 습득, 언어 이해력, 구어 산출 등의 언어처리과정에 영 향을 미친다(Gathercole \& Baddeley, 1993). 다시 말해 작업기억은 문장을 이해하고 표현하기 위해 문장 속에 포함된 단어의 의미를 이해하고, 순서대로 정보를 유지하며, 구문 구조를 파악하는 일련 의 과정에 영향을 미친다.

이렇듯 경도인지장애군에게서 나타나는 작업기억의 결함은 문 장이해력과 밀접한 연관이 있고, 이로 인해 원활한 의사소통에 어 려움을 겪게 된다. 다양한 연구 결과를 살펴보면 작업기억 감소는 복잡한 통사적 문장의 의미와 형태를 이해하는 데 영향을 미친다 고 하였다(Kemper, Thompson, \& Marquis, 2001; Small, Kemper, \& Lyons, 1997; Waters \& Caplan, 2001). 결국 경도인지장애군은 정 상 노년층에 비해 문법적· 구문적으로 덜 복잡한 언어를 이해하게 되고, 이로 인해 언어 표현에도 문제를 일으키게 된다(Kemper \& Sumner, 2001). 이는 작업기억이 감소될수록 입력된 정보를 조작하 고 처리하는 과정에 어려움을 보여 궁극적으로 복잡한 문장 따라 말하기 과제와 같은 언어처리과정에도 부정적 영향을 미친다는 Waters와 Caplan (2001)의 연구 결과와 일치한다.

경도인지장애군의 작업기억 결함은 문장 이해력과 문장 따라말 하기 결함과 동시에 언어 표현력을 측정하는 과제인 생성이름대기 과제에서 낮은 수행력을 야기한다(Kemper et al., 2001). 생성이름 대기 능력은 작업기억과 언어적 의미기억력 등의 다양한 인지적 과 제가 동시에 요구되는 매우 중요한 능력인데(Chertkow \& Bub, 1990), 경도인지장애군은 작업기억의 저하로 인하여 이러한 능력에 어려 움을 보이게 된다.

작업기억의 감소로 인한 문제는 언어 영역뿐만 아니라, 그 외의 인지 기능에도 영향을 미치고 있다. 다양한 연구에서 작업기억이 감소함에 따라 숫자 폭(digit span), 단어 폭(word span)과 같은 작 업기억 폭(working memory span)이 감소한다고 하였다(Braver \&
West, 2008; Carpenter, Miyake, \& Just, 1994; Kemper \& Sumner, 2001; Waters \& Caplan, 2001).

그러므로 경도인지장애군의 작업기억 감소와 이로 인해 나타나 는 인지 및 언어처리과정의 결함에 대한 해결책을 마련하고, 원활 한 의사소통을 촉진할 수 있는 중재가 절실하게 요구된다. 최근 들 어 경도인지장애군을 대상으로 한 작업기억 관련 연구가 증가함과 더불어 이러한 작업기억을 향상시키기 위한 작업기억중재에 대한 연구가 다양하게 이루어지고 있다(Angwin et al., 2006; Borella, Carretti, Riboldi, \& De Beni, 2010). Bokde 등(2010)은 작업기억중 재가 경도인지장애군의 인지 및 언어 기능 향상을 촉진하고 보상적 인 체계를 마련하는 데 유용하다고 하였다. Carretti, Borella, Fostinelli와 Zavagnin (2013)은 알츠하이머성 치매의 전구 증상이 될 수 있는 20명의 기억성(amnestic) 경도인지장애군에게 작업기억중재 를 실시하고 그 효과를 분석하였다. 중재 집단은 구어 작업기억 과 제를 중심으로 중재가 이루어졌고, 통제 집단은 기억력 관련 교육 활동을 받았다. 그 결과, 중재 집단이 중재 후 구어 작업기억 과제 외에 시공간 작업기억력(visuospatial working memory) 향상으로 의 전이 효과를 보였으며, 장기기억과 관련된 목록 회상 과제(list recall task)로의 전이 효과가 나타났다고 하였다. 그러나 통제 집단 은 이러한 전이 효과를 보이지 않았거나, 매우 제한된 향상을 나타 냈다고 하였다. 이러한 결과를 바탕으로 Carretti 등(2013)은 경도 인지장애군에게 실시한 작업기억중재가 인지 및 언어 능력의 향상 을 보였다고 해석하였다. Ahn과 Choi (2013)는 알츠하이머성 치매 환자 3 명을 대상으로 주 3 회기씩 총 40 회기의 작업기억중재를 실시 하였다. 그 결과, 문장이해력과 생성이름대기능력 등의 언어처리과 정에 향상을 보였다고 하였다. 이러한 결과를 바탕으로 경도인지장 애군에게 작업기억중재를 실시할 경우 긍정적인 효과를 가져올 것 이라고 예측할수 있다.

경도인지장애군을 대상으로 작업기억중재가 꾸준히 이루어지 고 있으나, 그 연구가 매우 제한적이다. 그리하여 본 연구에서는 경 도인지장애군을 대상으로 동사 운반구를 활용한 작업기억중재를 실시하고, 그 효과를 알아보고자 하였다. 동사 운반구를 활용한 작 업기억중재란, 작업기억 폭 향상을 위해 언어적 요소인 문장을 기 반으로 구성된 중재법으로, Morrison과 Chein (2011)이 설명한 전 략 훈련(strategy training)에 속한다. 전략 훈련이란, 작업기억의 효 율적인 부호화(encoding), 유지(maintenance), 인출(retrieval)을 위해 구성된 중재 유형으로 각각의 정보를 기억할 수 있는 능력을 향상시키기 위해, 기억을 돕는 추가적인 전략을 사용하도록 중재 하는 방법이다(예: McNamara \& Scott, 2001). 즉, 기억해야 할 정보 와 정보 사이의 의미적 지식(semantic knowledge)을 만들어 더 쉽 
게 기억할 수 있도록 전략을 사용하는 것이다. 전략 훈련을 이용한 작업기억중재는 중재한 작업기억 과제와 동시에 중재하지 않은 과 제로의 일반화 효과가 나타난다고 보고하고 있다(Carretti et al., 2013; Cavallini, Pagnin, \& Vecch, 2003; Comblain, 1994; Ford, Pelham, \& Ross, 1984; Turley-Ames \& Whitfield, 2003). 이러한 결과 들을 바탕으로 본 연구에서는 작업기억 향상을 위해 추가적인 전 략으로, 의미를 가진 동사를 활용하여 운반구를 구성하였다. 또한 문장의 형태가 고정되어 있는 동사 운반구를 사용함으로써, 추가 적으로 발생할 수 있는 과도한 역량 요구를 감소시키고자 하였다. 동사 운반구 문장 내에서 동사는 개별 단위를 큰 의미를 가진 단위 로 묶는 인지 과정인 청킹 메커니즘(chunking mechanism)의 역할 을 하게 된다. Breedin (1996)은 그의 연구에서 동사의 의미를 이용 하여 중재를 했을 때, 문장이해력과 산출 능력이 향상되었다고 하 였다. Edmonds와 Babb (2011)은 실어증 환자를 대상으로 동사 의 미역 강화 중재(verb network strengthening treatment)를 실시하 고 그 효과를 살펴보았다. 이들은 동사를 활용하여 문장 내에서 의 미적 관계를 연결시켜 중재를 한 결과, 중재의 목표 동사뿐 아니라, 비중재 동사로의 일반화 효과가 나타났다고 하였다. Edmonds와 $\mathrm{Babb}$ (2011)의 중재 방법을 국내에서 Kwag, Sung, Kim과 Cheon (2014)이 한국 실어증 환자를 대상으로 동사 의미역 강화 중재를 실 시한 결과, 중재 동사와 비중재 동사의 이름대기 수행력에 향상을 보였다고 하였다. 이러한 선행 연구들을 바탕으로 본 연구에서는 동사를 활용한 운반구를 제시하여 문장 사이의 의미 관계를 강화 시키고, 문장 내에 포함된 작업기억 폭을 향상시키는 전략 훈련 중 심 방법을 사용하여 중재를 실시하였다. 본 연구에서 사용한 중재 는 언어적 완충기(language buffer) 내의 정보를 효율적으로 저장하 고 인출할 수 있으며, 하위 목표 단어를 홀로 사용한 경우에 비해, 문장 내의 의미적 지식을 강화하고, 더 명확한 내용 전달을 유도하 며, 효율적인 단어 회상을 위한 새로운 전략을 제시하였다. 또한 이 러한 중재를 통해 경도인지장애군에게서 두드러지게 나타나는 작 업기억 감소와 그로 인해 나타나는 문장 따라말하기 능력, 문장이 해력, 작업기억력, 생성이름대기능력의 인지 및 언어처리과정에 미 치는 영향을 살펴보았다.

본 연구에 대한 연구 문제는 다음과 같다.

1. 동사 운반구를 활용한 작업기억중재 전·후에 따라 경도인지 장애군의 문장 따라말하기 과제에서 유의한 차이가 있는가?

2. 동사 운반구를 활용한 작업기억중재 전·후에 따라 경도인지 장애군의 문장이해 과제에서 유의한 차이가 있는가?

3. 동사 운반구를 활용한 작업기억중재 전·후에 따라 경도인지 장애군의 작업기억력에 유의한 차이가 있는가?
4. 동사 운반구를 활용한 작업기억중재 전· 후에 따라 경도인지 장애군의 생성이름대기 과제에서 유의한 차이가 있는가?

\section{연구 방법}

\section{연구대상}

본 연구는 서울 및 경기도에 거주하는 60 세 이상의 기억성 경도 인지장애군 8 명(남 1, 여 7)을 대상으로 중재를 실시하였다. 본 연구 에서는 고령자고용촉진법, 국민연금법, 노인복지법에서 정의하는 노인의 평균 연령인 60 세 이상을 대상자로 선정하였다. 모든 대상 자들은 신경과 전문의에 의한 신경심리학적 검사 등을 통해 기억성 경도인지장애로 진단되었다. 경도인지장애군은 Petersen (2004)의 진단기준에 근거하여 (1) 환자 및 보호자에 의한 주관적 기억장애 호소, (2) 동일 연령 및 교육수준에 비하여 비정상적인 기억력 저하, (3) 전반적인 인지 능력이 정상 범위, (4) 정상적인 일상생활 및 사회 생활, (5) 치매의 진단기준에 충족되지 않는 자를 대상으로 하였다. 또한 서울신경심리검사 2판(Seoul Neuropsychological Screening Battery, SNSB-II; Kang, Jang, \& Na, 2012)의 하위 항목 중 (1) 한국 판 간이정신진단검사(Korean-Mini Mental State Examination, KMMSE; Kang, Na, \& Hahn, 1997)에서 연령 및 교육 연수와 비교하 여 $16 \%$ ile 이상의 정상 규준에 속하고, (2) SNSB-II 전체 항목 검사 결과, 기억력 영역에서 $16 \%$ ile 미만이거나, 기억력을 포함한 하위 인 지 기능에서 2 가지 이상의 영역이 $16 \%$ ile 미만인 대상자로 선정하 였다. (3) SNSB-II의 임상치매척도(Clinical Dementia Rating, CDR; Hughes, Berg, Dazinger, Coben, \& Martin, 1982)가 .5이고, (4) SNSB-II의 한국형 도구적 일상생활 활동(Korean-Instrumental Activities of Daily Living, K-IADL; Won et al., 2002) 점수가.43 미 만, (5) SNSB-II의 단축형 노인우울척도 SGDS (Short version of the Geriatric Depression Scale; Jung, Kwak, Joe, \& Lee, 1997) 8 미만인 경우를 대상으로 하였다. 대상자별 배경정보 및 신경심리검사에 대 한 정보는 Table 1에 제시하였다.

\section{동사 운반구를 활용한 작업기억중재 프로그램 개발 중재 범주 및 단어 선정}

중재 범주는 Sung, Mo, Lee와 Sim (2014)의 노년층을 대상으로 한 범주별 본보기 산출빈도, 의미전형성, 친숙도 조사 결과, 중재가 필요한 명사 범주의 우선순위를 고려하여 총 4 개의 범주를 선정하 였다. 선정된 범주는 우선순위 1 위인 '음식', 2 위인 '옷'과 '신체 부 위', 우선순위 3 위인 '교통수단'이다. 범주별 하위 목표 단어는 Sung 등(2014)의 연구에서 나타난 범주별 의미전형성과 친숙도, 본보기 
Table 1. Demographic information and descriptive data from neuropsychological tests

\begin{tabular}{|c|c|c|c|c|c|c|c|c|c|}
\hline & P1 & P2 & P3 & P4 & P5 & P6 & P7 & P8 & $\mathrm{M}(\mathrm{SD})$ \\
\hline Age (yr) & 71 & 65 & 70 & 75 & 80 & 80 & 70 & 74 & $75.25(5.39)$ \\
\hline Gender & M & $\mathrm{F}$ & $\mathrm{F}$ & $\mathrm{F}$ & $\mathrm{F}$ & $\mathrm{F}$ & $\mathrm{F}$ & $\mathrm{F}$ & \\
\hline Education (yr) & 8 & 6 & 1 & 1 & 0.5 & 8 & 9 & 0.5 & $4.56(3.57)$ \\
\hline K-MMSE & 26 & 29 & 28 & 22 & 20 & 25 & 25 & 23 & $24.75(3.01)$ \\
\hline SVLT-immediate & 9 & 30 & 16 & 18 & 14 & 16 & 14 & 12 & $16.12(6.24)$ \\
\hline SVLT-delayed & 1 & 10 & 5 & 6 & 0 & 0 & 2 & 2 & $3.25(3.49)$ \\
\hline SVLT-recognition (true) & 11 & 12 & 8 & 11 & 10 & 10 & 8 & 6 & $9.5(2)$ \\
\hline SVLT-recognition (false) & 7 & 11 & 3 & 4 & 4 & 3 & 3 & 4 & $4.87(2.79)$ \\
\hline RCF--сору & 34 & 34 & 27.5 & 35 & 34 & 29 & 36 & 32 & 32.68 (2.98) \\
\hline RCFT-immediate & 23 & 13.5 & 8 & 13.5 & 8.5 & 3 & 16 & 2.5 & 11 (6.89) \\
\hline RCFT-delayed & 22 & 17.5 & 7.5 & 16 & 14 & 3 & 12.5 & 0 & $11.56(7.5)$ \\
\hline KCWST-color & 22 & 112 & 31 & 83 & 79 & 64 & 19 & 39 & 56.12 (33.58) \\
\hline KCWST-word & 109 & 112 & 85 & 108 & 45 & 57 & 112 & 73 & 87.62 (26.82) \\
\hline K-IADL & 0 & .1 & .1 & .1 & .1 & .4 & .4 & .2 & $.18(.15)$ \\
\hline SGDS & 0 & 5 & 7 & 0 & 6 & 1 & 7 & 6 & 4 (3.11) \\
\hline MCl-subtype & $\begin{array}{l}\text { Multiple } \\
\text { domain }\end{array}$ & $\begin{array}{l}\text { Multiple } \\
\text { domain }\end{array}$ & $\begin{array}{c}\text { Multiple } \\
\text { domain }\end{array}$ & $\begin{array}{c}\text { Multiple } \\
\text { domain }\end{array}$ & $\begin{array}{l}\text { Multiple } \\
\text { domain }\end{array}$ & $\begin{array}{l}\text { Multiple } \\
\text { domain }\end{array}$ & $\begin{array}{l}\text { Multiple } \\
\text { domain }\end{array}$ & $\begin{array}{c}\text { Multiple } \\
\text { domain }\end{array}$ & \\
\hline
\end{tabular}

$\mathrm{P}=$ participant; K-MMSE=Korean-Mini Mental State Examination (Kang, Na, \& Hahn, 1997); SNSB-II=Seoul Neuropsychological Screening Battery-II (Kang, Jang, \& Na, 2012); SVLT = Seoul Verbal Learning Test from SNSB-Il; RCFT = Rey Complex Figure Test from SNSB-Il; KCWST = Korean version of Color Word Stroop Test from SNSB-Il; KIADL= Korean-Instrumental Activities of Daily Living (Won et al., 2002); SGDS=Short version of the Geriatric Depression Scale (Jung, Kwak, Joe, \& Lee, 1997); MCl=mild cognitive impairment.

산출을 고려하여 Z-score 0 이상의 단어로 선정하였고, 1 음절의 단 어는 목표 단어에서 제외하였다. 교통수단 범주의 하위 목표 단어 는 비슷한 특징을 가진 단어(예: 기차-열차-전차 등)는 하나의 단어 (예: 기차)를 대표적으로 선정하였고, ‘옷'의 하위 단어 중 '내의'의 경우는 ‘내복’으로 대체하여 발음상의 혼동을 최소화하였다. 또한 음운 환경을 고려하여 '발가락-손가락'과 '발바닥-손바닥'등의 같 은 음절이 반복해서 중복되는 단어는 대표적으로 한 개씩만 선택 하였다. 본 연구의 목표 문장에 사용된 동사는 중재 범주별 2개씩 선정되었고, 교통수단의 경우 의미적으로 가장 많이 사용되는 ‘타 다' 동사 1 개를 선정하였다. 중재 범주 및 하위 목표 단어, 운반구 내 의 동사 목록은 Appendix 1에 제시하였다.

\section{동사 운반구 문장 구성}

중재에 사용된 문장은 중재 범주별 하위 명사와 의미적으로 관 련된 동사를 기반으로 구성된 운반구 형태이다. 문장의 형태는 국 어의 기본 어순인 '주어(Subject)+목적어(Object)+동사(Verb)'로 문장 내 의미적 요소를 고려하여 ' $\mathrm{S}_{1}+\mathrm{O}_{1}+\mathrm{V}_{1}+\mathrm{O}_{2}+\mathrm{V}_{2}$ '의 구조로 구성 되었다. 이러한 문장 구조의 목적어에 해당하는 ' $\mathrm{O}_{1}$ '과 ' $\mathrm{O}_{2}$ '의 단어 폭을 중재 난이도에 따라 3-6개까지 증가시켜, 문장의 길이를 6-9 어절로 늘려 단계별 난이도를 조절하였다. 예를 들어 '나는 코트를 입고, 지하철과 오토바이를 탔다'의 문장의 경우 $\mathrm{O}_{1}$ 의 '코트'와 $\mathrm{O}_{2}$
의 '지하철', ‘오토바이'로서, 목표 단어 폭 3, 총 6어절 길이의 문장 이 되는 것이다. 그러나 '나는 을 타고, 을 먹으러 갔다'의 문장 형 태에서 $\mathrm{V}_{2}$ 인 '먹으러 갔다'의 경우는 예외적으로 문장 내에서 $\mathrm{V}_{1}$ 인 '타다'와 의미상 자연스러운 문장을 위하여 '본용언+보조용언'의 형태로 추가하였으며, 목표 문장별 어절의 길이를 맞추기 위하여 하나의 어절로 간주하였다. 그리하여 중재 문장은 총 180 어절로 이 루어졌다.

중재 문장은 동사인 서술어의 어간에 종속적 연결어미를 더해 시 간 순서, 방법(수단), 목적(의도), 전환의 의미를 내포하며 문장 형태 별 4 개의 문장씩 총 24 개의 문장으로 구성되었다. 의미 관계에 따른 중재 문장의 구성은 Appendix 2에 제시하였다. 또한 회기별 중재 문장 및 문장 내 목표 단어 폭의 예시는 Appendix 3에 제시하였다.

\section{동사 운반구를 활용한 작업기억중재 프로토콜}

동사 운반구를 활용한 작업기억중재는 회기당 60 분씩 주 2 회기 의 구성으로 2주에 걸쳐 이루어졌다. 한 회기에 목표 단어 폭 3-6개 의 6-9어절 문장 4 개가 중재에 사용되었다. 처음 1-6회기까지 중재 후, 같은 문장 세트를 한 번 더 반복하여 총 12 회기의 중재가 이루 어졌다. 중재는 총 10 단계로 구성되어 있으며, 다음과 같다.

(1) 1단계-단어 폭 바로 따라말하기: 목표 단어 폭을 대상자에게 들려준 후, 바로 따라말하게 한다. 반응 여부와 상관없이 2 단 
계로 넘어간다.

(2) 2 단계-목표 문장 따라말하기: 1 단계에서 제시한 단어 폭으로 구성된 동사 운반구 문장을 들려준 후, 따라하도록 한다. 오반 응 시, 문장을 한 번 더 반복한 후, 따라말하게 한다.

(3) 3 단계-목표 문장 청킹 후, 따라말하기: 목표 단어 폭이 포함된 문장을 동사에 따라 두 개의 문장으로 나누어 들려주고 따라 하게 한다. 즉, ' $\mathrm{S}_{1}+\mathrm{O}_{1}+\mathrm{V}_{1}$ '을 들려주고 따라말하게 한 후, ' $\mathrm{S}_{1}+$ $\mathrm{O}_{2}+\mathrm{V}_{2}^{\prime}$ '의 문장을 제시하고 따라말하게 한다. 오반응 시, 한 번 더 들려주어 2차 반응을 유도한 후 다음 단계로 넘어간다.

(4) 4 단계-의문사 질문에 대답하기: 연구자는 목표 문장 속 목적 어에 대한 의문사 질문을 한다. 오반응 시, 전체 문장을 한 번 더 들려주어 2차 반응을 유도한 후 다음 단계로 넘어간다.

(5) 5 단계-단어 재인 단서 제공하기(word recognition cue): 문장 속 목표 단어 폭에 해당하는 범주의 그림 카드를 모두 제시한 후, 목표 그림 카드를 고르도록 한다. 제시되는 그림 카드의 개수는 음식 14 개, 옷 13 개, 신체부위 14 개, 교통수단 7 개이다. 오반응 시, 그림 카드를 소거하고 전체 문장을 한 번 더 들려 준 후, 2 차 반응을 유도한다. 두 번의 시도에서 모두 오반응을 보일 경우, 정반응을 제시하고 다음 단계로 넘어간다.

(6) 6단계-‘동사-명사' 매칭을 통한 문장 구성하기: 목표 문장에 포함된 동사 카드를 제시한 후, 5 단계에서 선택한 단어 그림 카드를 동사에 맞추어 분류하는 단계이다. 분류가 끝나면, 대 상자는 제시된 동사 카드와 그림 카드를 이용하여 목표 중재 문장을 구성한다. 그런 다음, 전체 문장 카드를 제시하고 그림 카드를 알맞은 문장 위치에 배열하고 문장을 재구성한다.

(7) 7단계-단서 제거 후 문장 재구성하기: 모든 시각적 단서를 제 거한 후, 대상자에게 중재 문장을 재구성하도록 한다.

(8) 8 단계-단어 폭 바로 회상하기: 문장 속의 목표 단어 폭을 순서 대로 회상하게 한다. 오반응 시, 6단계의 시각적 자극을 제시 한 후, 2차 반응을 유도한다.

(9) 9단계-단어 폭 거꾸로 회상하기: 문장 속의 목표 단어 폭을 거 꾸로 회상하게 한다. 오반응을 보일 경우, 8 단계를 반복하여 정반응을 요구한다.

(10) 10 단계-단서 없이 목표 문장 구성하기: 2단계에서 제시된 목 표 문장을 재구성하도록 한다. 오반응을 보일 경우, 6 단계의 과정을 반복하여 2차 반응을 요구하고, 반응 여부와 상관없 이 회기를 마무리한다.

구체적인 중재 프로토콜의 단계별 구성은 Appendix 4에 제시하 였다.

\section{사전·사후 평가 과제}

사전·사후 평가는 대상자의 집중력을 고려하여 중재 전·후 2 회 기에 걸쳐 이루어졌다. 평가 항목은 다음과 같다.

\section{문장 따라말하기 과제}

연구자는 24 개의 문장을 들려준 후, 대상자에게 따라하도록 하 고, 목표 문장의 어절을 기준으로 총 180 어절에 대한 정반응 점수 를 산출한 후 비교 분석하였다. 문장 따라말하기 과제의 목표 문장 은 Appendix 3 회기별 중재 목표 문장과 동일하다.

\section{문장이해과제}

중재 전·후 경도인지장애군의 문장이해력을 비교분석하기 위 하여 Sung (2015)의 문장이해과제를 실시하였다. 대상자는 제시된 문장을 듣고, 두 가지의 그림 중 정답을 선택하게 된다. 총점(36점) 에 대한 정반응 문항 수를 기준으로 정확도(정반응 점수/총점 $\times$ 100)를 산출하여 비교 분석하였다.

\section{작업기억 폭 과제}

중재 전·후의 언어적 및 비언어적 영역에서의 작업기억력을 비 교하기 위하여 연구자가 본 연구를 위하여 새롭게 고안한 (1) 중재 단어 폭 과제, (2) Sung (2011)의 단어 폭 과제(Word Span Task), (3) SNSB-II의 하위 항목인 숫자 폭 과제(Digit Span Test; Yeom, Park, Oh, Kim, \& Lee, 1992), (3) 노인 기억 장애 검사(Elderly Memory Disorder Scale, EMS; Choi, 2006)의 하위 항목인 시공간 폭 과제 (Visuospatial Span Test)를 실시하였다. 작업기억 폭 과제는 1초 간 격으로 목표 작업기억 폭을 제시한 후, 순서대로 따라하기, 거꾸로 따라하기를 수행하게 된다. 각 과제의 규준에 따라 정반응을 보일 경우 1 점을 부여하고 총점을 비교 분석하였다. 또한 두 번의 시행 모두에서 오반응을 보일 경우 검사를 중단한다.

\section{생성이름대기 과제}

중재 전· 후의 생성이름대기 능력을 비교하기 위하여 (1) 중재 범 주 유창성 과제(음식, 옷, 신체부위, 교통수단), (2) SNSB-II의 통제 단어 연상 검사(Controlled Oral Word Association Test, COWAT; Kang, Chin, Na, Lee, \& Park, 2000)의 의미 유창성 과제(동물, 가게 물건), (3) 동사 유창성 과제(Verb Fluency Task)를 실시하였다. 대 상자는 1 분 동안, 목표 명사나 동사를 최대한 많이 산출하게 된다. 채점은 각 검사의 규준에 따라 정반응 시 1 점을 부여하여 총점을 기준으로 비교 분석하였다. 본 연구에서 새롭게 고안된 중재 단어 폭작업기억 과제는 Appendix 5에 제시하였다. 


\section{자료의 통계적 처리}

본 연구에서는 경도인지장애군을 대상으로 실시한 동사 운반구 를 활용한 작업기억중재의 효과를 검증하기 위해 PASW (PASW statistics ver. 18.0)의 윌콕슨 부호순위 검정(Wilcoxon signed-ranks test)을 사용하여 비모수 검정을 실시하였다.

\section{연구 결과}

\section{문장 따라말하기 과제}

중재 전·후 문장 따라말하기 과제의 점수 차이가 통계적으로 유 의하였다 $(Z=-2.52, p<.05)$. 중재 후의 문장 따라말하기 과제의 평 균점수는 $144.62(\mathrm{SD}=10.5)$ 로 중재 전의 평균 점수 $112.12(\mathrm{SD}=10.79)$ 에 비해 유의하게 향상된 것으로 나타났다.

\section{문장이해과제}

중재 전·후 문장이해과제의 정확도(\%)의 차이가 통계적으로 유 의하였다 $(Z=-2.52, p<.05)$. 중재 후 문장이해과제의 평균 정확도 는 $82.63(\mathrm{SD}=7.08)$ 로 중재 전의 평균 정확도 $68.4(\mathrm{SD}=7.84)$ 와 비 교하였을 때, 유의한 향상을 보였다.

\section{작업기억 과제}

\section{중재 단어 폭 과제}

중재 전·후 중재 단어 폭 바로 따라말하기 과제의 점수 차이가 통계적으로 유의하였다 $(Z=-2.63, p<.05)$. 즉, 중재 후 단어 폭 바로 따라말하기 과제 점수는 평균 $3.25(\mathrm{SD}=.83)$ 로 중재 전의 평균 점 수 $1.87(\mathrm{SD}=.46)$ 에 비해 유의하게 증가하였다. 또한 중재 전· 후 중 재 단어 폭 거꾸로 따라말하기 과제의 점수 차이가 통계적으로 유 의하였다 $(Z=-2.63, p<.05)$. 중재 후 중재 단어 폭 거꾸로 따라말하

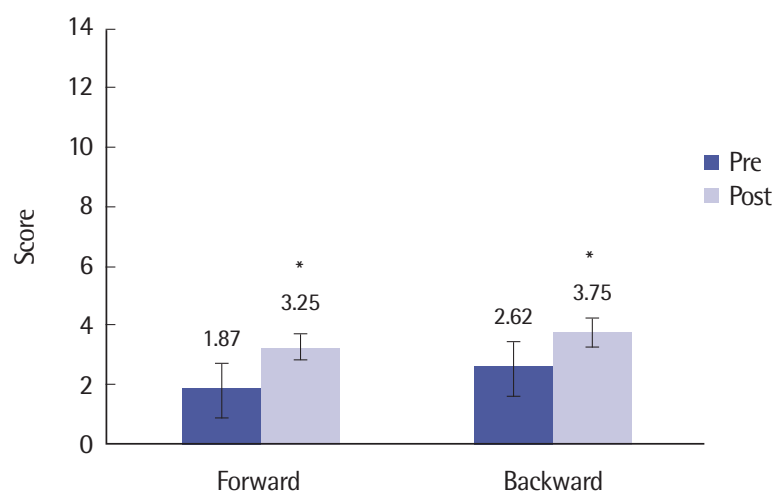

Figure 1. Pre-post comparisons on word span tasks from treated stimuli depending on the response order. ${ }^{*} p<.05$.
기 과제의 평균 점수는 $3.75(\mathrm{SD}=.74)$ 로 중재 전의 평균 점수 2.62 $(\mathrm{SD}=.88)$ 에 비해 유의하게 증가하였다. 중재 단어 폭 과제 유형에 따른 사전·사후 평균을 Figure 1에 제시하였다.

\section{비중재 단어 폭 과제}

중재 전· 후 중재에 포함되지 않은 단어로 이루어진 단어 폭 바로 따라말하기 과제(Sung, 2011)의 점수 차이가 통계적으로 유의하였 다 $(Z=-2.03, p<.05)$. 중재 후의 단어 폭 바로 따라말하기의 평균 점수는 $3.5(\mathrm{SD}=1.41)$ 로 중재 전의 평균 점수 $2(\mathrm{SD}=1.19)$ 에 비해 유의하게 증가하였다. 반면, 단어 폭 거꾸로 따라말하기 과제의 점 수는 통계적으로 유의하지 않았다 $(Z=-1.93, p>.05)$. 중재 후 과제 의 평균 점수는 $4(\mathrm{SD}=1.06)$ 로, 중재 전의 평균 점수 $3(\mathrm{SD}=1.06)$ 과 비교하였을 때, 유의한 향상을 보이지 않았다. 비중재 단어 폭 과 제 유형에 따른 사전·사후 평균을 Figure 2에 제시하였다.

\section{숫자 폭 과제}

중재 전·후 숫자 폭 바로 따라말하기 과제(Yeom et al., 1992)의 점수가 통계적으로 유의하지 않았으며 $(Z=-1.17, p>.05)$ 숫자 폭 거 꾸로 따라말하기 과제에서의 점수 차이가 통계적으로 유의하지 않 았다 $(Z=-.85, p>.05)$.

\section{시공간 폭 과제}

중재 전·후 비언어적 과제에서의 작업기억 능력을 비교하기 위 해 EMS (Choi, 2006) 하위 항목인 시공간 폭 과제를 실시하였다. 그 결과, 바로 따라하기 과제는 통계적으로 유의하지 않았다 $(Z=-.26$, $p>$.05). 중재 전 평균 점수는 $5.5(\mathrm{SD}=1.69)$ 로 중재 후의 평균 점수 $5.62(\mathrm{SD}=1.3)$ 와 비교하였을 때, 유의한 차이를 보이지 않았다. 반 면, 거꾸로 따라하기 과제의 점수 차이가 통계적으로 유의하였다

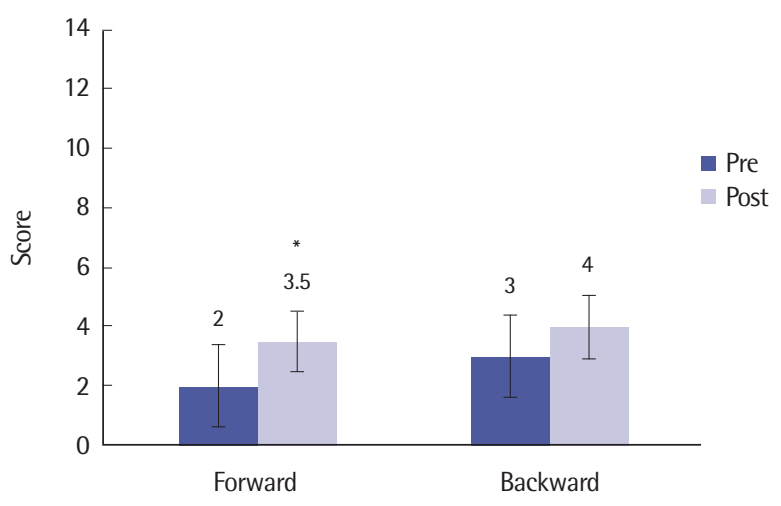

Figure 2. Pre-post comparisons on word span tasks from untreated stimuli depending on the response order. ${ }^{*} p<.05$. 


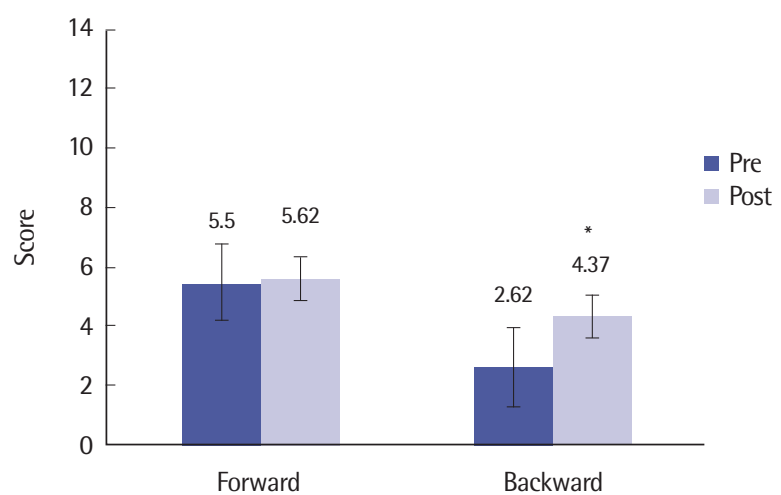

Figure 3. Pre-post comparisons on the visuospatial span task depending on the response order. ${ }^{*} p<.05$.

$(Z=-2.13, p<.05)$. 중재 후의 시공간 폭 거꾸로 따라하기 과제의 평 균 점수는 $4.37(\mathrm{SD}=.74)$ 로 중재 전의 평균 점수 $2.62(1.68)$ 에 비해 유의하게 증가하였다. 시공간 폭 과제 유형에 따른 사전·사후 평균 을 Figure 3에 제시하였다.

\section{생성이름대기 과제}

중재 의미 유창성 과제

중재 전·후 생성이름대기 능력을 비교하여 위하여 네 가지 중재 범주에 대한 의미 유창성 과제를 실시하였다. 그 결과, '음식' $(Z=$ $-2.2, p<.05)$, '옷 $(Z=-2.38, p<.05)$, '신체부위' $(Z=-2.52, p<.05)$ 및 '교통수단' $(Z=-2.4, p<.05)$ 범주에서 중재 후 수행력이 유의하게 증가한 것으로 나타났다. 중재 전·후에 따른 평균 및 표준편차에 대한 자료는 Figure 4에 제시하였다.

\section{비중재 의미 유창성 과제}

중재에 포함되지 않은 범주에서 생성이름대기 능력으로의 일반 화 효과를 검증하기 위하여 COWAT의 하위 항목 중 의미 유창성 과제를 실시한 결과, 중재 전·후 ‘동물’ 범주의 유창성 과제 점수가 통계적으로 유의하였다 $(Z=-2.03, p<.05)$. 중재 후의 점수는 평균 점수 $13.5(\mathrm{SD}=2.13)$ 로 중재 전의 평균 점수 $10.25(\mathrm{SD}=3.53)$ 와 비 교하였을 때, 유의한 향상을 보였다. '가게 물건' 범주의 유창성 과 제 점수 역시 통계적으로 유의하였다 $(Z=-2.1, p<.05)$. 중재 후의 점수는 평균 $15.87(\mathrm{SD}=4.42)$ 로 중재 전의 평균 $10(\mathrm{SD}=6.5)$ 과 비 교하였을 때, 유의한 향상을 보였다.

\section{동사 유창성 과제}

중재 전·후 동사 생성이름대기 능력으로의 일반화 효과를 검증 하기 위하여 동사 유창성 과제를 실시한 결과, 그 차이가 통계적으

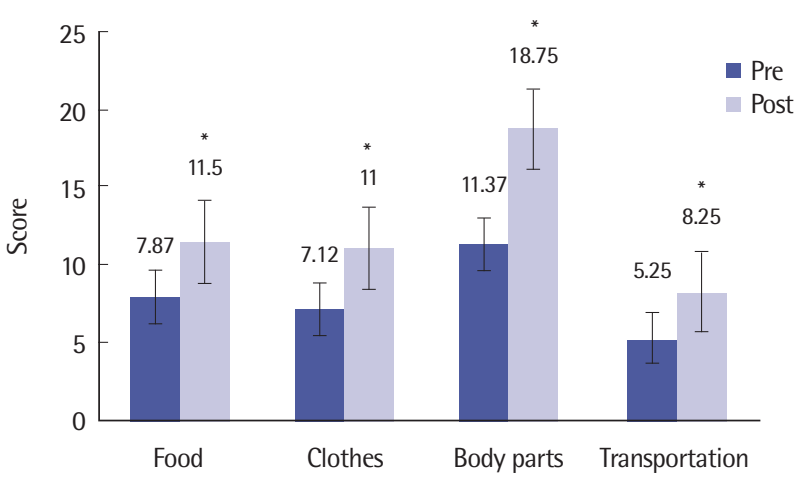

Figure 4. Pre-post comparisons of semantic fluency tasks for each category. ${ }^{*} p<.05$.

로 유의하였다 $(Z=-2.21, p<.05)$. 중재 후, 과제의 평균 점수는 7.42 $(\mathrm{SD}=2.03)$ 로 중재 전의 평균 점수 $2.87(\mathrm{SD}=2.5)$ 과 비교하였을 때, 유의한향상을 나타냈다.

\section{논의 및 결과}

본 연구는 동사 운반구 활용한 작업기억중재를 8 명의 기억성 경 도인지장애군에게 6 주간 총 12 회기 실시하고 중재 전·후 수행력을 비교하였다. 본 연구에서는 문장의 통사적 구조에 의미 단위를 늘 려가는 형태의 운반구 문장을 기반으로 작업기억중재법을 새롭게 구성하고 실시하였다. 한국어의 특성상 동사 앞의 구성 요소를 늘 려갈수록 문장 성분과 의미가 풍부해지는 표현이 가능하게 된다. 이러한 통사적 구조와 의미적 구조를 동시에 문장으로 구성하여 작업기억중재를 한 연구가 거의 없으며, 또한 이를 인지적 영역에 어 려움을 보이는 경도인지장애군을 대상으로 한 중재 연구가 매우 드 물다. 그러므로 통사적 구조에 의미를 강화시킨 작업기억중재를 경 도인지장애군에게 실시한 데 큰 의미가 있다.

중재 결과, 중재 후에 중재에 사용한 문장 따라말하기 수행력에 서 긍정적인 향상을 보였다. 다시 말해 청각적으로 제시되는 문장 내의 구성 성분을 더 많이 기억하여 따라말하는 능력으로의 향상 이 일어났다고 해석할 수 있다. 중재 문장은 ' $\mathrm{S}_{1}+\mathrm{O}_{1}+\mathrm{V}_{1}+\mathrm{O}_{2}+\mathrm{V}_{2}$ '의 형태로 구성되어 있고, 목적어의 개수에 따라 문장의 길이가 증가 하게 되는데, 대상자들은 중재 후에 목적어에 해당하는 단어를 더 많이 기억하여 산출한 것으로 나타났다. 이러한 결과는 중재 후, 중 재 단어 폭 과제 수행력의 향상이 뒷받침해주고 있다. 또한 중재 문 장은 동사에 종속적 연결어미를 더하여 문장 내에서 시간순서, 방 법, 목적, 전환 동의 의미를 내포하고 있으며, 중재 단계 중 청킹 메 커니즘을 이용하는 단계 역시 작업기억 내에서 부호화(encoding) 
되어 의미적 처리 부담(semantic processing load)을 줄여 수행력 향상에 긍정적인 영향을 미친 것으로 볼수 있다. 즉, 작업기억이 향 상됨에 따라서 긴 문장을 기억하고 산출할 수 있는 문장 따라말하 기 능력이 향상되는 것을 확인할수 있었다.

동사 운반구를 활용한 작업기억중재의 효과는 비중재 문장을 청각적으로 듣고 이해하는 문장이해과제로의 일반화 효과를 보였 다. 중재 전 · 후, 경도인지장애군의 문장이해과제의 정확도를 비교 한 결과, 중재 후의 문장이해과제의 정확도가 통계적으로 유의하 게 향상되었다. 이는 중재를 통하여 문장이해력에 매우 중요한 요 소인 작업기억과 함께 비중재 문장을 이해하는 데 긍정적인 효과 를 가져왔다고 해석할 수 있다. Kemper와 Sumner (2001)는 작업기 억과 같은 인지적 감소로 인하여 문법적 - 구문적으로 복잡한 문장 을 이해하고 표현하는 데 어려움을 보여 이러한 영역의 향상이 필 요하다고 하였고, 본 연구에서는 작업기억중재를 통하여 비중재 문 장에 대한 이해력을 향상시켰다는 데 큰 의의를 둘 수 있다. 이는 작 업기억중재가 언어 이해력을 증진시키는 전이 효과(transfer effect) 를 보였다는 Carretti 등(2013)의 연구 결과와 그 맥락을 함께 한다. 본 연구를 통해작업기억이 문장이해력을 뒷받침 해주는 근본적인 인지적 기제이므로 작업기억을 향상시킬 경우, 문장이해력에 긍정 적인 영향을 준다는 것을 확인할 수 있었다. 또한 문장을 저장하고 조작하는 등의 처리과정이 작업기억의 근본적인 인지적 기제가 될 수 있음을 밝히는 또 하나의 증거가 되고 있다. 본 연구는 언어적 단 위를 이용한 중재 방법과 작업기억 폭 향상에 초점을 맞춘 중재 방 법 중 어떠한 영역을 먼저 중재하여야 하는지, 또한 어떠한 영역을 우선적으로 중재할 경우 일반화 효과가 크게 나타나는 효율적인 중재가 이루어지는지에 대한 기초 연구 및 시사점을 제공하였다.

본 연구는 중재 및 비중재 작업기억의 향상과 일반화 효과를 입 증하는 데 큰 역할을 하였다. 먼저 중재한 단어로 이루어진 단어 폭 과제의 수행력 향상을 보였다. 이러한 중재 단어 폭 과제의 향상은 문장 따라말하기 수행력의 향상에 긍정적인 영향을 미쳤는데, 목 적어에 해당하는 단어 폭을 더 많이 기억함에 따라, 문장 내에서 기 억하고 회상하는 언어적 단위가 길어진 것을 알 수 있었다. 또한 동 사 운반구를 활용한작업기억중재는 중재 영역뿐 아니라 비중재 작 업기억으로의 일반화 효과를 도출했다. 중재 전·후 비중재 영역 작 업기억 폭 과제로의 일반화 효과를 살펴보기 위하여 비중재 단어 폭 과제, 숫자 폭 과제, 시공간 폭 과제를 실시하여 비교하였다. 그 결과, 비중재 단어로 이루어진 Sung (2011)의 단어 폭 과제에서 단 어 폭 바로 따라말하기 수행력의 향상 및 일반화 효과가 나타났다. 또한 통계적으로 유의하지는 않았으나, 비중재 단어 폭 거꾸로 따 라말하기에서 대상자 개별 점수가 향상된 것을 볼 수 있었다. 다시
말해 중재 후, 중재하지 않은 언어 정보를 저장하고 처리하는 네트 워크를 활성화시켜 수행력 향상을 이끌어 냈다고 해석할 수 있다. 이는 기존의 다양한 연구 결과와 일치한다(Borella et al., 2010; Richmond, Morrison, Chein, \& Olson, 2011). 그러나 숫자 폭 과제에서 는 중재 전 · 후 대상자의 개별 점수의 향상은 있으나, 통계적으로 유의한 효과가 나타나지 않았다. 마지막으로 시공간 폭 과제에서 중재 전·후, 시공간 폭 바로 따라하기 과제의 수행력의 차이는 통 계적으로 유의하지 않았고, 시공간 폭 거꾸로 따라하기 과제에서는 유의한 향상을 보여 일반화를 관찰할 수 있었다. 이를 종합하여 살 펴보면, 동사 운반구를 활용한 작업기억중재는 경도인지장애군의 작업기억에 긍정적 영향을 미쳤고, Just와 Carpenter (1992)의 작업 기억용량 이론(working memory capacity theory)에 근거하여, 입 력된 정보를 유지하고 조작할 수 있는 과정의 활성화를 일으킨 데 그 의의가 있다고 할 수 있다. 이는 경도인지장애군을 대상으로 작 업기억중재를 실시한 결과, 작업기억이 향상되었다는 다양한 연구 결과와 일치한다(Bokde et al., 2010; Borella et al., 2010; Carretti et al., 2013).

마지막으로 중재 후, 중재 의미 유창성 과제와 비중재 의미 유창 성 과제의 수행력이 향상되어, 생성이름대기 능력으로의 일반화 효 과가 나타났다. 중재 전·후, 중재에 사용된 네 가지 범주(음식, 옷, 신체부위, 교통수단)의 의미 유창성 과제에서 전반적인 수행력 향 상이 나타났다. 이와 같은 결과는 동사 운반구를 활용한 작업기억 중재 내의 범주별 목표 하위 명사들이 중재 단계에서 지속적으로 노출되고, 이러한 명사를 조작하고 처리하는 과정의 활성화가 제한 된 시간 내에 더 다양한 단어를 빠르게 인출하는 능력의 향상을 일 으켰다고 해석할 수 있다. 비중재 생성이름대기 능력의 일반화 효과 를 살펴보기 위해, SNSB-II의 하위 항목 중 COWAT의 의미 유창 성 과제를 실시하였고, 그 결과 '동물'과 '가게 물건'의 의미 유창성 점수가 유의하게 향상되어 일반화 효과를 나타냈다. 또한 중재하지 않은 동사에 대한 동사 의미 유창성 과제의 수행력이 향상되어 일 반화 효과를 보였다. 본 연구에서 사용한 중재 프로토콜은 동사를 활용하여 문장 내의 의미적 처리과정을 강조하였고, 이로 인하여 중재 하지 않은 동사에서의 생성이름대기 능력이 향상되는 결과를 가져왔다. Chertkow와 Bub (1990)에 따르면, 생성이름대기 능력은 언어적 의미 기억력과 주의력, 작업기억, 전반적인 모니터링 등의 다 양한 인지적 과제가 동시에 요구되는 매우 중요한 능력이라고 하였 다. 본 연구에서는 중재 및 비중재 영역에서 생성이름대기 능력의 긍정적인 향상을 밝혔으며, 이러한 결과는 동사를 활용한 작업기억 중재가 전반적인 인지 기능을 향상시키는 데 효과가 있다는 것을 증 명하였다. Edmonds와 Babb (2011) 그리고 Kwag 등(2014)은 실어증 
환자를 대상으로 동사를 활용한 중재 후, 문장 내에서 동사와 그 외 의 구성 성분 간의 네트워크 관계가 강화되어 비중재 동사로의 일 반화 효과가 나타난다고 하여, 본 연구의 결과와 그 맥락을 함께 한 다. 다시 말해 본 연구에서 실시한 중재 방법은 명사와 동사의 의미 처리과정을 활성화시켜 전반적인 생성이름대기 영역에서 긍정적인 효과가 나타나 매우 효과적인 중재법이라는 것을 보여주었다.

이를 종합해서 살펴보면, 동사를 활용한 작업기억중재는 중재 영 역인 문장 따라말하기 능력과 중재 단어 작업기억에서 긍정적인 수 행력 향상을 보였으며, 비중재 영역인 문장이해력, 비중재 단어 작업 기억, 시공간 작업기억, 생성이름대기 능력으로의 일반화 효과를 가 져와, 이와같은 언어처리과정에 두드러지는 결함을 보이는 경도인지 장애군에게 효과적인 중재법이라는 것을 밝히는 데 큰 의의가 있다.

본 연구의 제한점 및 후속 연구에 대한 제언은 다음과 같다. 본 연구는 경도인지장애군을 대상으로 작업기억중재를 실시한 데 그 의의가 있으나, 대상자의 수가 8 명으로 제한되어 있다. 그러므로 추 후 연구에서는 더 많은 경도인지장애군을 대상으로 동사 운반구 를 활용한 작업기억중재의 효과 및 일반화에 대해 살펴볼 필요가 있다. 또한작업기억중재 후, 중재하지 않은 문장이해과제 수행력이 향상된 것으로 보아, 문장을 이해하는 능력으로의 일반화 효과가 일어난 것을 알 수 있었다. 후속 연구에서는 중재 후 문장이해 수행 력의 일반화가 미치는 영향이 문장의 유형 즉, 통사 구조에 따라 다 르게 나타나는지에 대한 심도 있는 연구가 필요하리라 생각된다.

\section{REFERENCES}

Ahn, G. M., \& Choi, Y. G. (2013). The effect of working memory enhancement program on word fluency and sentence comprehension in dementia of Alzheimer's type patients. Journal of Psychology and Behavior, 5, 75-110.

Angwin, A. J., Chenery, H. J., Copland, D. A., Cardell, E. A., Murdoch, B. E., \& Ingram, J. C. (2006). Searching for the trace: the influence of age, lexical activation and working memory on sentence processing. Journal of Psycholinguistic Research, 35, 101-117.

Baddeley, A. D., \& Hitch, G. J. (1974). Working memory. Psychology of Learning and Motivation, 8, 47-89.

Bokde, A. L., Karmann, M., Born, C., Teipel, S. J., Omerovic, M., Ewers, M., ... \& Hampel, H. (2010). Altered brain activation during a verbal working memory task in subjects with amnestic mild cognitive impairment. Journal of Alzheimer's Disease, 21, 103-118.

Borella, E., Carretti, B., Riboldi, F., \& De Beni, R. (2010). Working memory training in older adults: evidence of transfer and maintenance effects. Psy- chology and Aging, 25, 767-778.

Braver, T. S., \& West, R. (2008). Working memory, executive control, and aging. The Handbook of Aging and Cognition, 3, 311-372.

Breedin, S. D. (1996). Patterns of verb impairment in aphasia: an analysis of four cases. Cognitive Neuropsychology, 13, 51-92.

Carpenter, P. A., Miyake, A., \& Just, M. A. (1994). Working memory constraints in comprehension: evidence from individual differences, aphasia, and aging. In M. A. Gernsbacher (Ed.), Handbook of psycholinguistics (pp. 1075-1122). San Diego, CA: Academic Press.

Carretti, B., Borella, E., Fostinelli, S., \& Zavagnin, M. (2013). Benefits of training working memory in amnestic mild cognitive impairment: specific and transfer effects. International Psychogeriatrics, 25, 617-626.

Cavallini, E., Pagnin, A., \& Vecchi, T. (2003). The rehabilitation of memory in old age: effects of mnemonics and metacognition in strategic training. Clinical Gerontologist, 26, 125-141.

Chertkow, H., \& Bub, D. (1990). Semantic memory loss in dementia of Alzheimer's type. Brain, 113, 397-417.

Choi, J. Y. (2006). Elderly memory disorder scale user manual. Seoul: Hakjisa.

Comblain, A. (1994). Working memory in Down syndrome: training the rehearsal strategy. Down Syndrome Research and Practice, 2, 123-126.

DeDe, G., Caplan, D., Kemtes, K., \& Waters, G. (2004). The relationship between age, verbal working memory, and language comprehension. Psychology and Aging, 19, 601-616.

Edmonds, L. A., \& Babb, M. (2011). Effect of verb network strengthening treatment in moderate-to-severe aphasia. American Journal of Speech-Language Pathology, 20, 131-145.

Ford, C. E., Pelham, W. E., \& Ross, A. O. (1984). Selective attention and rehearsal in the auditory short-term memory task performance of poor and normal readers. Journal of Abnormal Child Psychology, 12, 127-141.

Gathercole, S. E., \& Baddeley, A. D. (1993). Phonological working memory: a critical building block for reading development and vocabulary acquisition? European Journal of Psychology of Education, 8, 259-272.

Hughes, C. P., Berg, L., Danziger, W. L., Coben, L. A., \& Martin, R. (1982). A new clinical scale for the staging of dementia. British Journal of Psychiatry, 140, 566-572.

Jung, I. K., Kwak, D. I., Joe, S. H., \& Lee, H. S. (1997). A study of standardization of Korean form of Geriatric Depression Scale (KGDS). Journal of Korean Geriatric Psychiatry, 1, 61-72.

Just, M. A., \& Carpenter, P. A. (1992). A capacity theory of comprehension: individual differences in working memory. Psychological Review, 99, 122- 
149.

Kang, S. K., Kim, D. Y., Seok, D. I., Cho, H. J., \& Choi, K. H. (2001). Studies on communication disorders in the elderly to improve their quality of life. Journal of the Research Institute for Special Education \& Rehabilitation Science, 40, 109-134.

Kang, Y., Chin, J. H., Na, D. L., Lee, J., \& Park, J. S. (2000). A normative study of the Korean version of Controlled Oral Word Association Test (COWAT) in the elderly. Korean Journal of Clinical Psychology, 19, 385-392.

Kang, Y., Jang, S. M., \& Na, D. L (2012). Seoul Neuropsychological Screening Battery (2nd ed.). Seoul: Human Brain Research \& Consulting.

Kang, Y., Na, D. L., \& Hahn, S. (1997). A validity study on the Korean MiniMental State Examination (K-MMSE) in dementia patients. Journal of the Korean Neurological Association, 15, 300-308.

Kemper, S., \& Sumner, A. (2001). The structure of verbal abilities in young and older adults. Psychology and Aging, 16, 312-322.

Kemper, S., Rash, S., Kynette, D., \& Norman, S. (1990). Telling stories: the structure of adults' narratives. European Journal of Cognitive Psychology, 2, 205-228.

Kemper, S., Thompson, M., \& Marquis, J. (2001). Longitudinal change in language production: effects of aging and dementia on grammatical complexity and propositional content. Psychology and Aging, 16, 600-614.

Kim, S. Y. (2003). Clinical characteristics of mild cognitive impairment. Dement Neurocognitive Disorders, 2, 96-100.

Kwag, E. J., Sung, J. E., Kim, Y. H., \& Cheon, H. J. (2014). Effects of verb network strengthening treatment on retrieval of verbs and nouns in persons with aphasia. Communication Sciences \& Disorders, 19, 89-98.

McNamara, D. S., \& Scott, J. L. (2001). Working memory capacity and strategy use. Memory \& Cognition, 29, 10-17.

Morrison, A. B., \& Chein, J. M. (2011). Does working memory training work? The promise and challenges of enhancing cognition by training working memory. Psychonomic Bulletin \& Review, 18, 46-60.

Petersen, R. C. (2004). Mild cognitive impairment as a diagnostic entity. Journal of Internal Medicine, 256, 183-194.
Petersen, R. C., Smith, G. E., Waring, S. C., Ivnik, R. J., Tangalos, E. G., \& Kokmen, E. (1999). Mild cognitive impairment: clinical characterization and outcome. Archives of Neurology, 56, 303-308.

Richmond, L. L., Morrison, A. B., Chein, J. M., \& Olson, I. R. (2011). Working memory training and transfer in older adults. Psychology and Aging, 26, 813-822.

Small, J. A., Kemper, S., \& Lyons, K. (1997). Sentence comprehension in Alzheimer's disease: effects of grammatical complexity, speech rate, and repetition. Psychology and Aging, 12, 3-11.

Sung, J. E. (2011). The reliability and validity of short-term and working memory pointing tasks developed for clinical populations with speech and language disorders. Korean Journal of Communication Disorders, 16, 185-201.

Sung, J. E. (2015). Effects of syntactic structure on sentence comprehension ability as a function of the canonicity of word-order and its relation to working memory capacity in Korean-speaking elderly adults. Communication Sciences \& Disorders, 20, 24-33.

Sung, J. E., Mo, K. O., Lee, J. S., \& Sim, H. S. (2014). Production frequency, semantic typicality, and familiarity of noun exemplars for elderly adults. Communication Sciences \& Disorders, 19, 213-225.

Turley-Ames, K. J., \& Whitfield, M. M. (2003). Strategy training and working memory task performance. Journal of Memory and Language, 49, 446-468.

Waters, G. S., \& Caplan, D. (2001). Age, working memory, and on-line syntactic processing in sentence comprehension. Psychology and Aging, 16, 128-144.

Won, C. W., Yang, K. Y., Rho, Y. G., Kim, S. Y., Lee, E. J., Yoon, J. L., ... \& Yoon, D. K. (2002). The development of Korean activities of daily living (K-ADL) and Korean instrumental activities of daily living (K-IADL) scale. Journal of the Korean Geriatrics Society, 6, 107-120.

Wright, H. H., Capilouto, G. J., Srinivasan, C., \& Fergadiotis, G. (2011). Story processing ability in cognitively healthy younger and older adults. Journal of Speech, Language, and Hearing Research, 54, 900-917.

Yeom, T. H., Park, Y. S., Oh, K. J., Kim, J. K., \& Lee, Y. H. (1992). Korean Wechsler Adult Intelligence Scale (K-WAIS): manual. Seoul: Guidance Korea. 
Appendix 1. 중재 범주 및 하위 목표 단어

\begin{tabular}{llll}
\hline 범주 & \multicolumn{1}{c}{ 하위 목표 명사 } & 목표 동사 \\
\hline 음식 & 두부, 갈비, 잡채, 곰탕, 미역국, 비빔밥, 콩국수, 청국장, 불고기, 삼계탕, 육개장, 수제비, 볶음밥, 김치찌개(총 14개) & 먹다, 만들다 \\
옷 & 잠옷, 양복, 남방, 잠바, 팬티, 반팔, 코트, 러닝, 내복, 조끼, 등산복, 티셔츠, 원피스(총 13개) & 입다, 벗다 \\
신체부위 & 얼굴, 치아, 눈썹, 어깨, 입술, 이마, 배꼽, 가슴, 발목, 손목, 종아리, 엉덩이, 손가락, 발가락(총 14개) & 씻다, 다치다 \\
교통수단 & 택시, 버스, 기차, 지하철, 자동차, 비행기, 오토바이(총 7개) & 타다 & \\
\hline
\end{tabular}

Appendix 2. 중재 문장의 의미적 구성

\begin{tabular}{|c|c|c|c|}
\hline 의미관계 & 연결어미 & 문장 형태 & 예시 \\
\hline 시간, 순서 & 고 & $\begin{array}{l}\text { 나는 을 입고, 을 탔다. } \\
\text { 나는 을 입고, 을 먹었다. }\end{array}$ & $\begin{array}{l}\text { 나는 코트를 입고 지하철과 오토바이를 탔다. } \\
\text { 나는 남방을 입고 볶음밥과 청국장을 먹었다. }\end{array}$ \\
\hline 방법 & 고 & 나는 을 타고, 을 먹으러 갔다. & 나는 버스와 지하철을 타고, 비빔밥과 두부와 청국장을 먹으러 갔다. \\
\hline 목적 & 려고 & 나는 을 씻으려고, 을 벗었다. & 나는 종아리를 씻으려고, 양복과 원피스를 벗었다. \\
\hline 전환 & $\sim$ 다가 & $\begin{array}{l}\text { 나는 을 탔다가, 을 다쳤다. } \\
\text { 나는 을 만들다가, 을 다쳤다. }\end{array}$ & $\begin{array}{l}\text { 나는 버스를 탔다가, 손가락과 눈썹을 다쳤다. } \\
\text { 나는 수제비를 만들다가, 얼굴과 손목을 다쳤다. }\end{array}$ \\
\hline
\end{tabular}

Appendix 3. 회기별 중재 문장

\begin{tabular}{|c|c|c|c|}
\hline 회기 & 단어 폭 & 목표 문장 & 총 어절수 \\
\hline \multirow[t]{4}{*}{$1 \& 7$} & Span 3 & 나는 버스를 탔다가, 손가락과 눈썹을 다쳤다. & 6 \\
\hline & Span 4 & 나는 잠바와 내복을 입고, 김치찌개와 불고기를 먹었다. & 7 \\
\hline & Span 5 & 나는 미역국과 갈비를 만들다가, 눈썹과 엉덩이와 배꼽을 다쳤다. & 8 \\
\hline & Span 6 & 나는 팬티와 내복과 조끼를 입고, 비행기와 택시와 지하철을 탔다. & 9 \\
\hline \multirow[t]{4}{*}{$2 \& 8$} & Span 3 & 나는 남방을 입고, 볶음밥과 청국장을 먹었다. & 6 \\
\hline & Span 4 & 나는 육개장과 잡채를 만들다가, 종아리와 얼굴을 다쳤다. & 7 \\
\hline & Span 5 & 나는 등산복과 팬티를 입고, 자동차와 비행기와 기차를 탔다. & 8 \\
\hline & Span 6 & 나는 버스와 자전거와 기차를 탔다가, 배꼽과 이마와 발바닥을 다쳤다. & 9 \\
\hline \multirow[t]{4}{*}{$3 \& 9$} & Span 3 & 나는 수제비를 만들다가, 얼굴과 손목을 다쳤다. & 6 \\
\hline & Span 4 & 나는 잠옷과 러닝을 입고, 자전거와 버스를 탔다. & 7 \\
\hline & Span 5 & 나는 발목과 치아를 씻으려고, 티셔츠와 남방과 반팔을 벗었다. & 8 \\
\hline & Span 6 & 나는 자전거와 기차와 자동차를 타고, 미역국과 잡채와 삼계탕을 먹으러 갔다. & 9 \\
\hline \multirow[t]{4}{*}{$4 \& 10$} & Span 3 & 나는 코트를 입고, 지하철과 오토바이를 탔다. & 6 \\
\hline & Span 4 & 나는 손목과 발바닥을 씻으려고, 조끼와 양복을 벗었다. & 7 \\
\hline & Span 5 & 나는 버스와 지하철을 타고, 비빔밥과 두부와 청국장을 먹으러 갔다. & 8 \\
\hline & Span 6 & 나는 육개장과 갈비와 콩국수를 만들다가, 어깨와 치아와 가슴을 다쳤다. & 9 \\
\hline \multirow[t]{4}{*}{$5 \& 11$} & Span 3 & 나는 종아리를 씻으려고, 양복과 원피스를 벗었다. & 6 \\
\hline & Span 4 & 나는 자동차와 택시를 타고, 삼계탕과 콩국수를 먹으러 갔다. & 7 \\
\hline & Span 5 & 나는 택시와 자전거를 탔다가, 입술과 손가락과 어깨를 다쳤다. & 8 \\
\hline & Span 6 & 나는 런닝과 등산복과 잠옷을 입고, 불고기와 곰탕과 비빔밥을 먹었다. & 9 \\
\hline \multirow[t]{4}{*}{$6 \& 12$} & Span 3 & 나는 택시를 타고, 김치찌개와 두부를 먹으러 갔다. & 6 \\
\hline & Span 4 & 나는 지하철과 오토바이를 탔다가, 가슴과 이마를 다쳤다. & 7 \\
\hline & Span 5 & 나는 원피스와 코트를 입고, 볶음밥과 곰탕과 수제비를 먹었다. & 8 \\
\hline & Span 6 & 나는 엉덩이와 입술과 발목을 씻으려고, 잠바와 티셔츠와 반팔을 벗었다. & 9 \\
\hline 총 합계 & & & 180 \\
\hline
\end{tabular}


Appendix 4. 중재 프로그램 단계별 구성

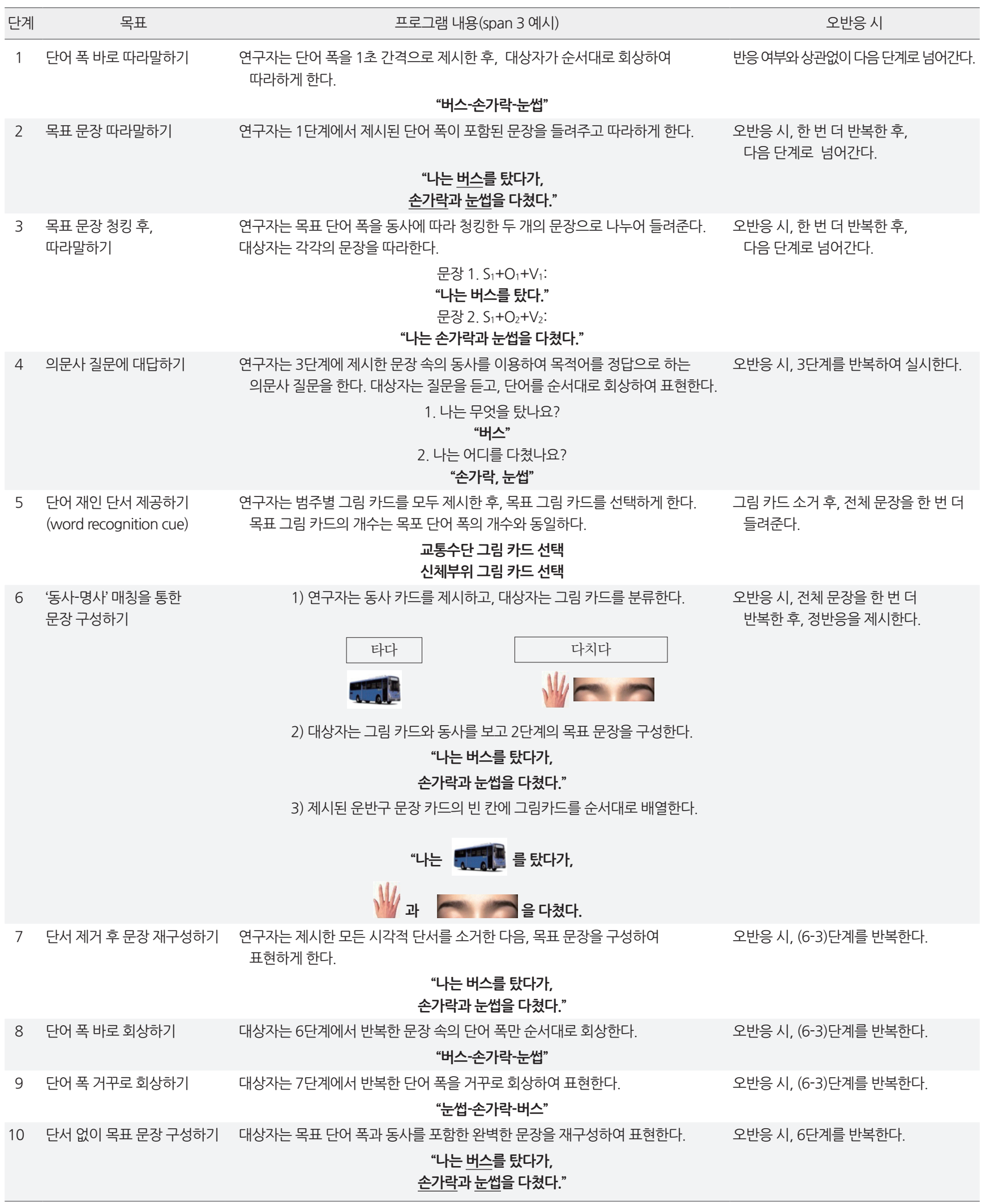


Appendix 5. 중재 단어 폭 과제

\begin{tabular}{|c|c|c|}
\hline \multirow{2}{*}{ 문항 } & \multicolumn{2}{|c|}{ 목표 단어 폭 } \\
\hline & 바로 따라말하기(forward) & 거꾸로 따라말하기(backward) \\
\hline $1-1$ & 콩국수-티셔츠-이마 & 자전거-이마 \\
\hline $1-2$ & 갈비-종아리-자전거 & 두부-비행기 \\
\hline $2-1$ & 택시-원피스-손목-볶음밥 & 남방-갈비-엉덩이 \\
\hline $2-2$ & 티셔츠-기차-불고기-눈썹 & 어깨-볶음밥-코트 \\
\hline $3-1$ & 남방-지하철-가슴-곰탕-비행기 & 얼굴-지하철-미역국-반팔 \\
\hline $3-2$ & 입술-비빔밥-등산복-잡채-팬티 & 남방-자동차-눈썹-삼계탕 \\
\hline $4-1$ & 눈썹-코트-종아리-청국장-양복-발바닥 & 기차-비빔밥-티셔츠-입술-곰탕 \\
\hline $4-2$ & 삼계탕-반팔-이마-내복-비행기-콩국수 & 엉덩이-잠옷-미역국-택시-이마 \\
\hline $5-1$ & 불고기-배꼽-조끼-엉덩이-기차-미역국-팬티 & 불고기-손목-코트-잡채-비행기-가슴 \\
\hline $5-2$ & 두부-잠옷-수제비-발바닥-택시-볶음밥-얼굴 & 내복-곰탕-티셔츠-갈비-지하철-팬티 \\
\hline $6-1$ & 자동차-갈비-입술-비빔밥-어깨-등산복-반팔-치아 & 치아-양복-삼계탕-두부-자동차-배꼽-조끼 \\
\hline $6-2$ & 엉덩이-남방-버스-청국장-코트-자동차-손목-곰탕 & 비빔밥-얼굴-버스-손목-반팔-자전거-가슴 \\
\hline $7-1$ & 두부-자전거-얼굴-잠옷-수제비-버스-내복-삼계탕-잡채 & 택시-눈썹-팬티-어깨-내복-버스-잠옷-볶음밥 \\
\hline $7-2$ & 가슴-지하철-치아-양복-배꼽-미역국-조끼-원피스-어깨 & 입술-기차-양복-치아-불고기-조끼-배꼽-잡채 \\
\hline
\end{tabular}




\section{국문초록}

\section{동사 운반구를 활용한 작업기억중재가 경도인지장애군의 언어처리과정에 미치는 효과}

최수진 ${ }^{1} \cdot$ 성지은 ${ }^{1} \cdot$ 정지향 ${ }^{2} \cdot$ 김건하 $^{2,3}$

${ }^{1}$ 이화여자대학교 대학원 언어병리학과, ${ }^{2}$ 이화여자대학교 목동병원 신경과, ${ }^{3}$ 이화뇌융합과학연구원

배경 및 목적: 경도인지장애군은 작업기억과 언어 능력의 저하를 나타내고, 언어처리과정에 결함을 보인다. 본 연구에서는 경도인지장 애군을 대상으로 동사 운반구를 활용한 작업기억중재를 실시하고 언어처리과정에 미치는 효과를 살펴보았다. 방법: 본 연구는 8명의 경도인지장애군을 대상으로, 주 2회 60 분씩, 총 12 회기의 중재가 실시되었다. 중재 전. 후 문장 따라말하기, 문장이해, 작업기억, 생성이 름대기 수행력을 비교하기 위하여 사전·사후 평가를 실시하였다. 중재에 사용된 중재법은 새롭게 고안된 방법으로 의미를 가진 동사를 이용하여 운반구(carrier phrase)를 구성하고, 이를 활용하여 작업기억 폭을 향상시키는 작업기억중재를 실시하였다. 결과: 문장 따라 말하기 과제와 문장이해과제에서 통계적으로 유의한 향상을 보였다. 작업기억 과제 중 중재 단어 폭, 비중재 단어 폭 바로 따라하기, 시 공간폭 거꾸로 따라하기 과제에서 수행력 향상을 나타냈다. 생성이름대기 수행력 평가를 위한 중재 의미 유창성 과제, 비중재 의미 유 창성 과제 및 동사 유창성 과제에서 유의한 향상을 보였다. 논의 및 결론: 동사 운반구를 이용한 작업기억중재는 경도인지장애군의 문 장 따라말하기 및 비중재 문장이해력의 향상이라는 일반화 효과를 가져왔다. 비중재 작업기억 향상으로의 전이 효과를 나타냈으며, 중 재 및 비중재 명사와 동사의 생성이름대기능력 향상이라는 일반화 효과를 가져왔다. 즉, 중재하지 않은 인지 및 언어 영역의 네트워크를 활성화시켜 경도인지장애군의 언어처리과정에 긍정적인 효과를 가져왔다.

핵심어: 경도인지장애, 작업기억중재, 동사 운반구, 언어처리과정

이 논문은 2014년도 정부(교육부)의 재원으로 한국연구재단의 지원을 받아 연구되었음(NRF-2014S1A5A8018080).

\section{참고문헌}

강수균, 김동연, 석동일, 조홍중, 최경희(2001). 노인성 질환자의 삶의 질 제고를 위한 의사소통 문제 연구. 특수교육재활과학연구, 40, 109-134. 강연욱, 나덕렬, 한승혜(1997). 치매환지들을 대상으로 한 K-MMSE의 타당도연구. 대한신경과학회지, 15, 300-308.

강연욱, 장승민, 나덕렬(2012). 서울신경심리검사 2판. 서울: 휴브알엔씨.

강연욱, 진주희, 나덕렬, 이정희, 박재설(2000). 통제 단어 연상 검사(Controlled Oral Word Association Test)의 노인 규준 연구. 한국심리학회지: 임 상, 19, 385-392.

곽은정, 성지은, 김연희, 전희정(2014). 동사의미역강화중재가 실어증 환자의 동사 및 명사 이름대기에 미치는 효과. 언어청각장애연구, 19, 89-98. 김상윤(2003). 경도인지장애의 임상소견. 대한치매학회지, 2, 96-100.

성지은(2011). 말언어장애군의 단기기억 및 작업기억용량 측정을 위한 지시하기과제 개발 예비 연구: 재검사 신뢰도 및 타당도. 언어청각장애연구, 16 , $185-201$.

성지은(2015). 한국어 어순 규범성과 문장유형이 노년층 문장이해능력에 미치는 영향 및 작업기억용량과의 관계. 언어청각장애연구, 20, 24-33. 성지은, 모경옥, 이지선, 심현섭(2014). 노년층을 대상으로 한 명사 범주별 본보기 산출빈도, 의미전형성 및 친숙도 연구. 언어청각장애연구, 19, 213-

225.

안길만, 최양규(2011). 작업기억 강화 프로그램이 알츠하이머형 치매 환자의 단어 유창성과 문장이해력에 미치는 효과. 심리행동연구, 5, 75-110. 염태호, 박영숙, 오경자, 김정규, 이영호(1992). 한국판 웩슬러 성인용 지능 검사(K-WAIS): 실시 요강. 서울: 한국가이던스. 정인과, 곽동일, 조숙행, 이현수(1997). 한국형 노인우울검사표준화 연구. 노인정신의학, 1, 61-72.

최진영(2006). 노인 기억장애 검사 실시 요강. 서울: 학지사. 